poll, Pine Siskin, American Goldfinch, Red Crossbill, White-winged Crossbill, Rufoussided Towhee, Baird's Sparrow, Slatecolored Junco, Tree Sparrow, Chipping
Sparrow, Clay-colored Sparrow, Harris Sparrow, White-crowned Sparrow, White throated Sparrow, Fox Sparrow, Lincoln Sparrow, Song Sparrow.

\section{FEEDING The Hungry}

BY LAURA HOYTE*

I have always been interested in birds. Sometimes I used to throw out a few crumbs for them on a cold day, feeling that a full stomach would keep them warm the following night. I never ceased to marvel that a bird as small as a chickadee could survive 40-below weather, yet its cheerful song and acrobatic antics would make me think he was enjoying it.

In 1964, after we moved into a cottage on the edge of Pike Lake, I had more time to notice how many different types of birds there were around. Of course, the friendly little chickadees were present in numbers. I began feeding them, at first by hanging pieces of suet on branches of trees just outside the kitchen window, and putting little bits of bread or left-over pie, tarts, etc, in the crotch of a maple. (It wasn't a very good place, as the food kept falling in the snow.)

I especially remember having a piece of peach pie, along with a butter tart, completely consumed by one Robin. Being first up on the morning of January 2, I went to the window to see how many of our feathered friends were having breakfast. Just below the window on the walk was a robin which seemed to drag one wing a little. It looked so miserable I was sure it was hungry. Sure that it would never find the pie in the

\footnotetext{
* Mrs. Laura Hote lives at, Pike Lake, a small resort community 18 miles south-west of Saskatoon. Now a Provincial Park, Pike Lake is an oxbow, part of the ancient bed of the South Saskatchewan River. Set in sandy country, the lake is heavily treed on the north and west sides. Rich in bird life, it is probabty the best single birding area adjacent to the city.
}

tree, I tried to decide, while putting th kettle on for coffee, how I could ge some food out to it without frightenin it away. But by the time I was free $t$ look again, I was surprised to see it i the tree eating the pie.

That day began sunny but cold. A day long the Robin ate, then flew to si in the sunny doorway of the unoccupie doghouse which faced the south and wa protected from the wind by chokecherry bush. It was still eating the evening when it was almost too dark fo me to see. It was there again the nes morning. How early it had started, didn't know but it seemed unable to sto eating. The weather turned bad later $\mathrm{i}$ the day and a blizzard was forecas Janice, our daughter, home for holiday and I began to worry. Where could th Robin sleep out of the storm? We mad a makeshift house out of an orange bo and filled it with straw. Putting on ot warm coats, we went out in the stor and fastened it to the chokecherry bus just above the doghouse where th Robin had perched when he wasn eating or sitting in the doghouse. Fro what I know now, I am sure it was waste of time. I don't think a Robi would ever go into a place like that. W even checked later with a flashlight, bl we did not see the bird. The next mo ning it was not at the food tray, nor di it show up during the day. We did ne see it again, and I always felt that it ha eaten itself to death, although it coul of course, have perished in the storn Since that time we have had as many four Robins at our feed tray in Januar:

I had to find something better to hol the food. When we emptied the Chris mas box of oranges, I took half th boards off one side, and nailed the oth side to the trunk of the tree about $4 \mathrm{fe}$ from the ground and just 6 feet from th kitchen window. From there I cou 


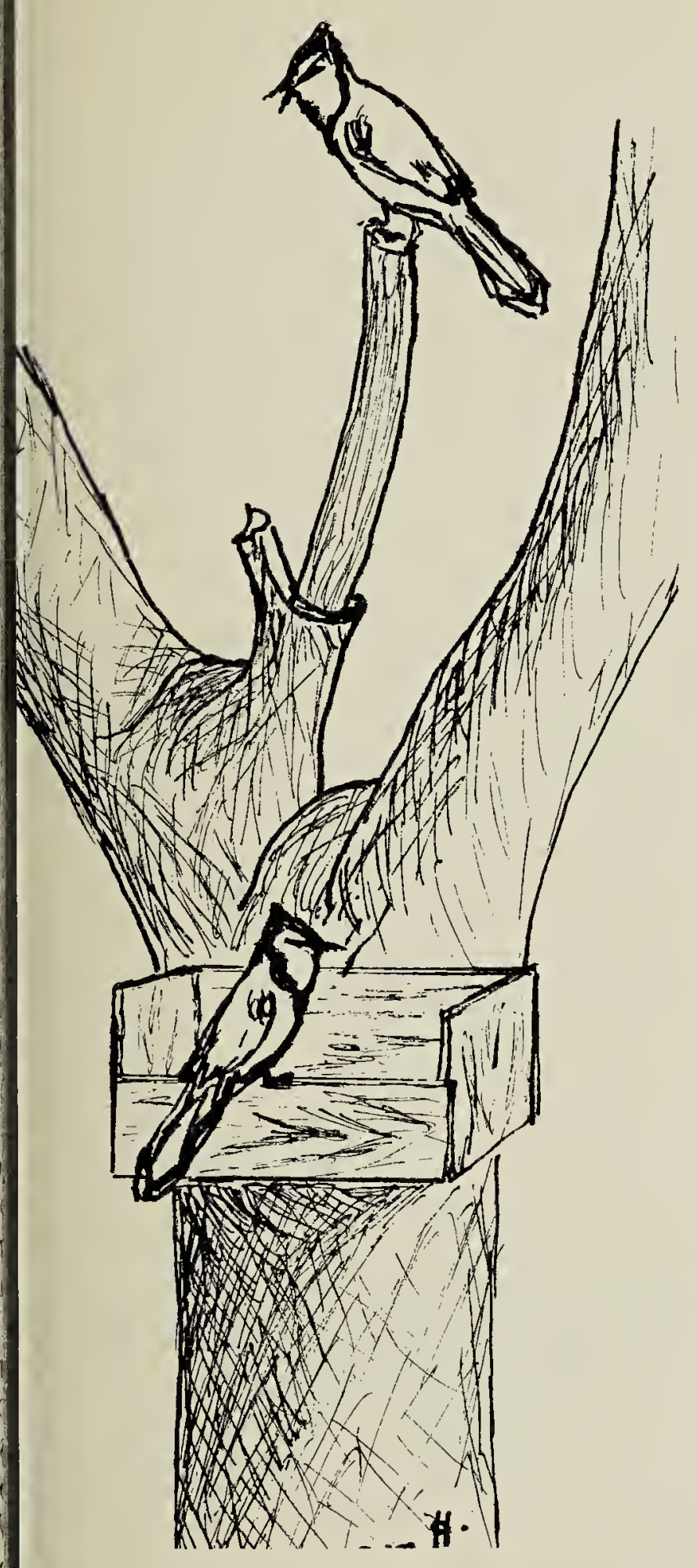

vatch the goings and comings while I repared meals and washed dishes.

Mr. Frank Roy, who teaches students City Park Collegiate (which our two aughters attended), often stops by on ird expeditions to say hello as he, too, interested in the birds that collect at he feeder. When he first came, I knew nly the familiar birds and often asked im about different species I had seen. knowing my interest, he and Dr. Bernie sollop from the Canadian Wildlife Serice send me cards to fill out each honth for their records. I became more nterested after I got books to identify each new bird that came to the yard. To my surprise I learned that nearly 20 species of sparrows occur at one season or another at Pike Lake!

As more and more birds noticed the food and came to eat, my interest grew. The space provided soon became too small and we had to find other places to put food. Hairy and Downy Woodpeckers were now daily visitors to the suet, as many as six feeding at once. Grosbeaks and waxwings came but would not eat from the feeder; they ate the seeds of the Manitoba maple, chokecherries and other berries that stayed on the trees. In March and again in October up to 20 juncos fed regularly at our tray. In the winter Starlings occasionally dropped by. Chickadees were abundant. I actually counted 15 on one occasion, and I knew there were more in the nearby woods. We had a cement birdbath in the yard, which I filled with crumbs, different kinds of grain and suet. The Blue Jays had now joined the numbers of visitors and they and the

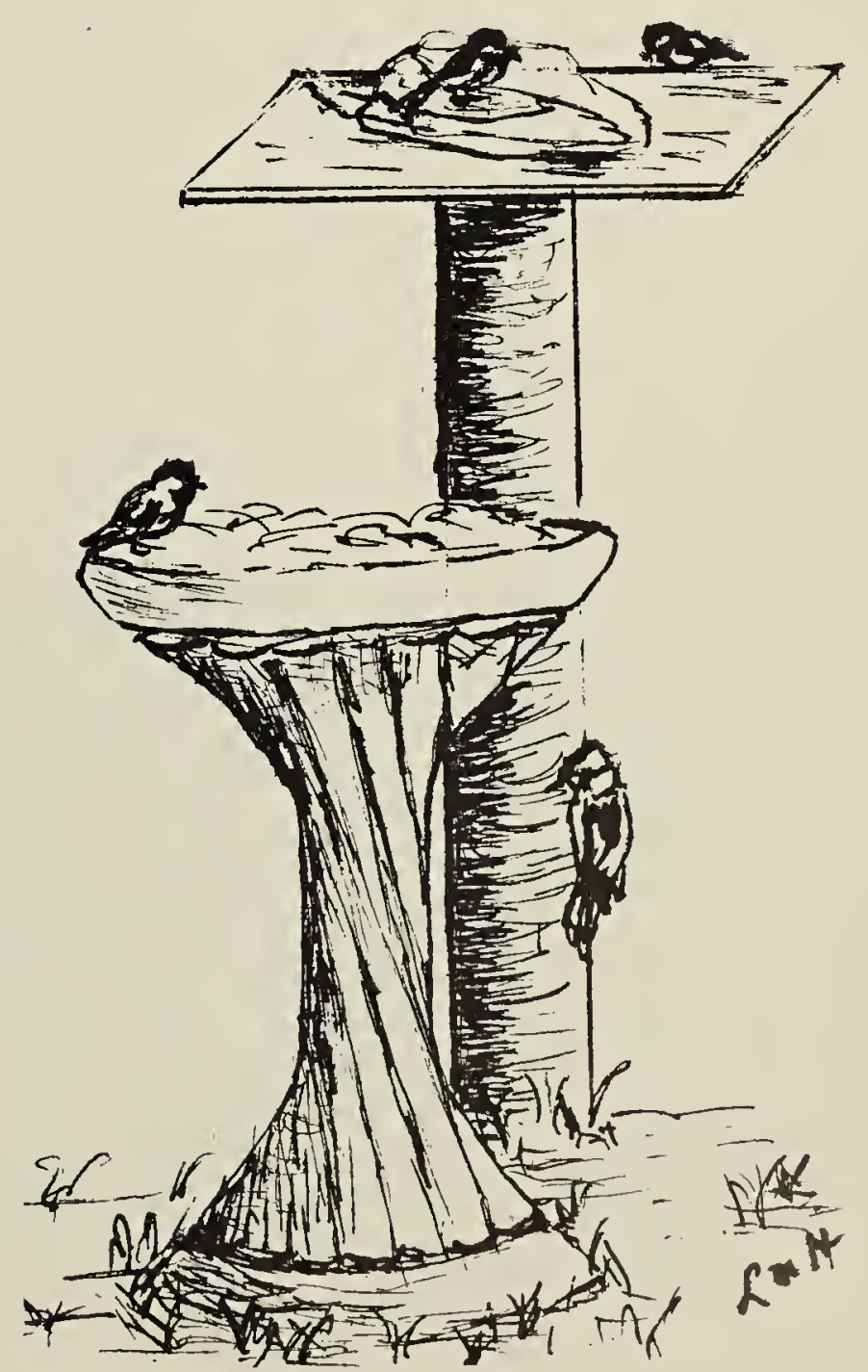


magpies carried away the bigger pieces of suet. It's quite a sight to see eight Blue Jays and eight magpies crowded around the feeders at one time.

At this point I must introduce our Samoyed dog, Nickie, since he plays a part in our story. He had figured out that I chased the magpies away but not the other birds and on days that he felt energetic he decided to chase them too. As he jumped and barked at them, one would lead him away while the others took the bread and suet from the feeder. Both Nickie and the magpies claim the uncleared wooded lot belonging to the Church across the road. While he is over there exploring, the magpies follow above from tree to tree, scolding all the while. One day a magpie flew off with a large piece of suet, almost too big to carry, so Nickie took off too. When the magpie dropped the suet half way across the church yard, Nickie retrieved it and started home. He always brings anything he finds to me in exchange for something tasty from the fridge. The magpie followed closely, as it wasn't about to give up if there was a chance retrieving its suet. Needless to sa Nickie got his tasty exchange. The were days when Nickie gave up con pletely and lay at the end of th driveway, but the magpies proceeded see how far they could go with hir They would pretend to find a good su ply of food no less than $1-1 / 2$ feet fro his front feet or 2 inches from his ta but when he persistently looked off the distance as if he didn't even kno they were there, they finally gave up ar went about their business.

I soon realized that I had to find better way to secure the suet since to much of it was going to waste. Char Kelman, of the Saskatoon Quick Freez gave us all the suet we could use, most it in large pieces. Joe, my husband, cut big piece of plywood, 20" by 20 ", ar we nailed it on a post bedside the bir bath, securing the chunks of suet and with large nails.

In 1969 we had a lot of snow - o of those years when you never see a ra bit track anywhere and food was scar
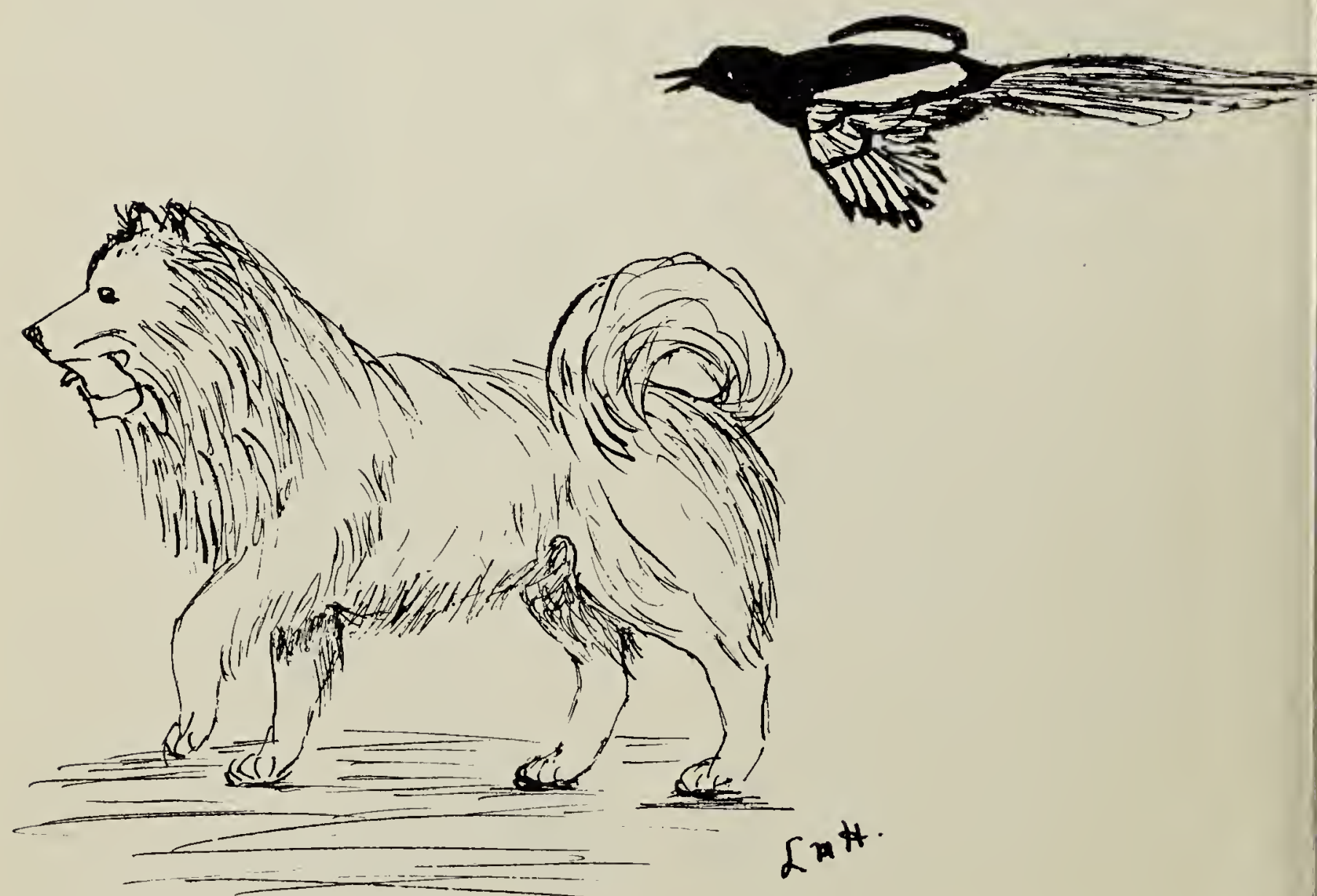
